\title{
Rymosia azorensis
}

\author{
Assessment by: Nunes, R. \& Borges, P.A.V.
}

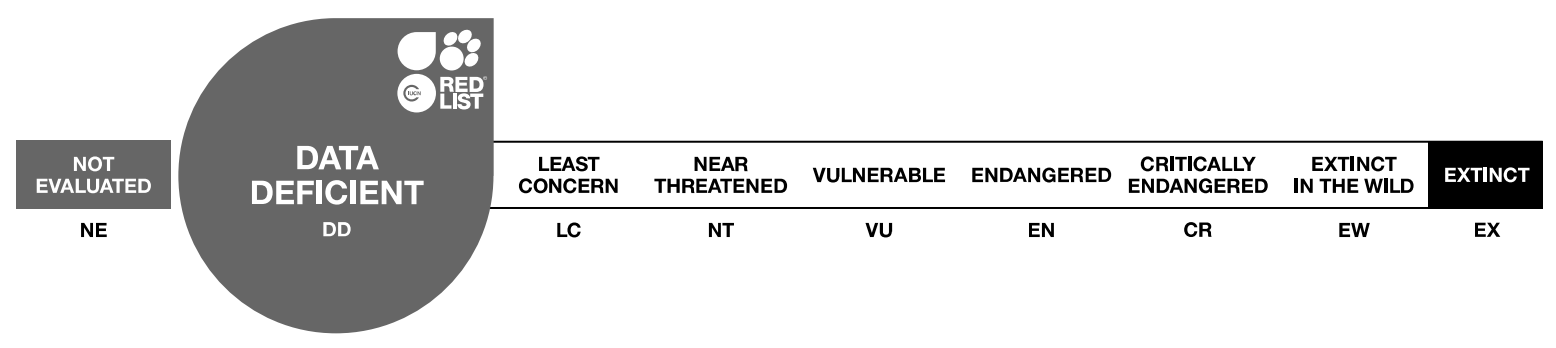

View on www.iucnredlist.org

Citation: Nunes, R. \& Borges, P.A.V. 2020. Rymosia azorensis. The IUCN Red List of Threatened Species 2020: e.T124915769A124930761. https://dx.doi.org/10.2305/IUCN.UK.20203.RLTS.T124915769A124930761.en

Copyright: (C) 2020 International Union for Conservation of Nature and Natural Resources Reproduction of this publication for educational or other non-commercial purposes is authorized without prior written permission from the copyright holder provided the source is fully acknowledged.

Reproduction of this publication for resale, reposting or other commercial purposes is prohibited without prior written permission from the copyright holder. For further details see Terms of Use.

The IUCN Red List of Threatened Species ${ }^{T M}$ is produced and managed by the IUCN Global Species Programme, the IUCN Species Survival Commission (SSC) and The IUCN Red List Partnership. The IUCN Red List Partners are: Arizona State University; BirdLife International; Botanic Gardens Conservation International; Conservation International; NatureServe; Royal Botanic Gardens, Kew; Sapienza University of Rome; Texas A\&M University; and Zoological Society of London.

If you see any errors or have any questions or suggestions on what is shown in this document, please provide us with feedback so that we can correct or extend the information provided. 


\section{Taxonomy}

\begin{tabular}{|c|c|c|c|c|}
\hline Kingdom & Phylum & Class & Order & Family \\
\hline Animalia & Arthropoda & Insecta & Diptera & Mycetophilidae \\
\hline
\end{tabular}

Scientific Name: Rymosia azorensis Chandler \& Ribeiro, 1995

\section{Assessment Information}

Red List Category \& Criteria: $\quad$ Data Deficient ver 3.1

Year Published: 2020

Date Assessed: $\quad$ March 28, 2018

\section{Justification:}

Rymoza azorensis is an endemic species of the Azores (Portugal), that was described from S. Miguel island. This species was recorded in a single area in the vicinity of hot springs, in a site that is currently highly degraded. From the historical data, this species had a very small Extent of Occurrence $\left(8 \mathrm{~km}^{2}\right)$ and Area of Occupancy $\left(8 \mathrm{~km}^{2}\right)$, and it is possible that this species has declined in the past, as a result of human activity. The present situation of this species needs to be further assessed, and further research is needed into its population, distribution, threats, ecology and life history. Conservation/restoration of native habitats and humid areas could also potentially aid this species' conservation. However, based upon the lack of recent in data regarding this species population, distribution, threats and ecology, this species is assessed as Data Deficient (DD).

\section{Geographic Range}

\section{Range Description:}

Rymoza azorensis is an Azorean-endemic fly species that was described from the island of S. Miguel (Azores, Portugal) (Borges et al. 2010). It is known from a single site, Furnas, a disturbed location with hot springs. Based on the old historical data (Frey 1945), the Extent of Occurrence (EOO) would be ca. 8 $\mathrm{km}^{2}$ and the Area of Occupancy (AOO) is also ca. $8 \mathrm{~km}^{2}$. However, there is no recent information regarding the distribution of this species.

\section{Country Occurrence:}

Native, Extant (resident): Portugal (Azores) 


\section{Distribution Map}

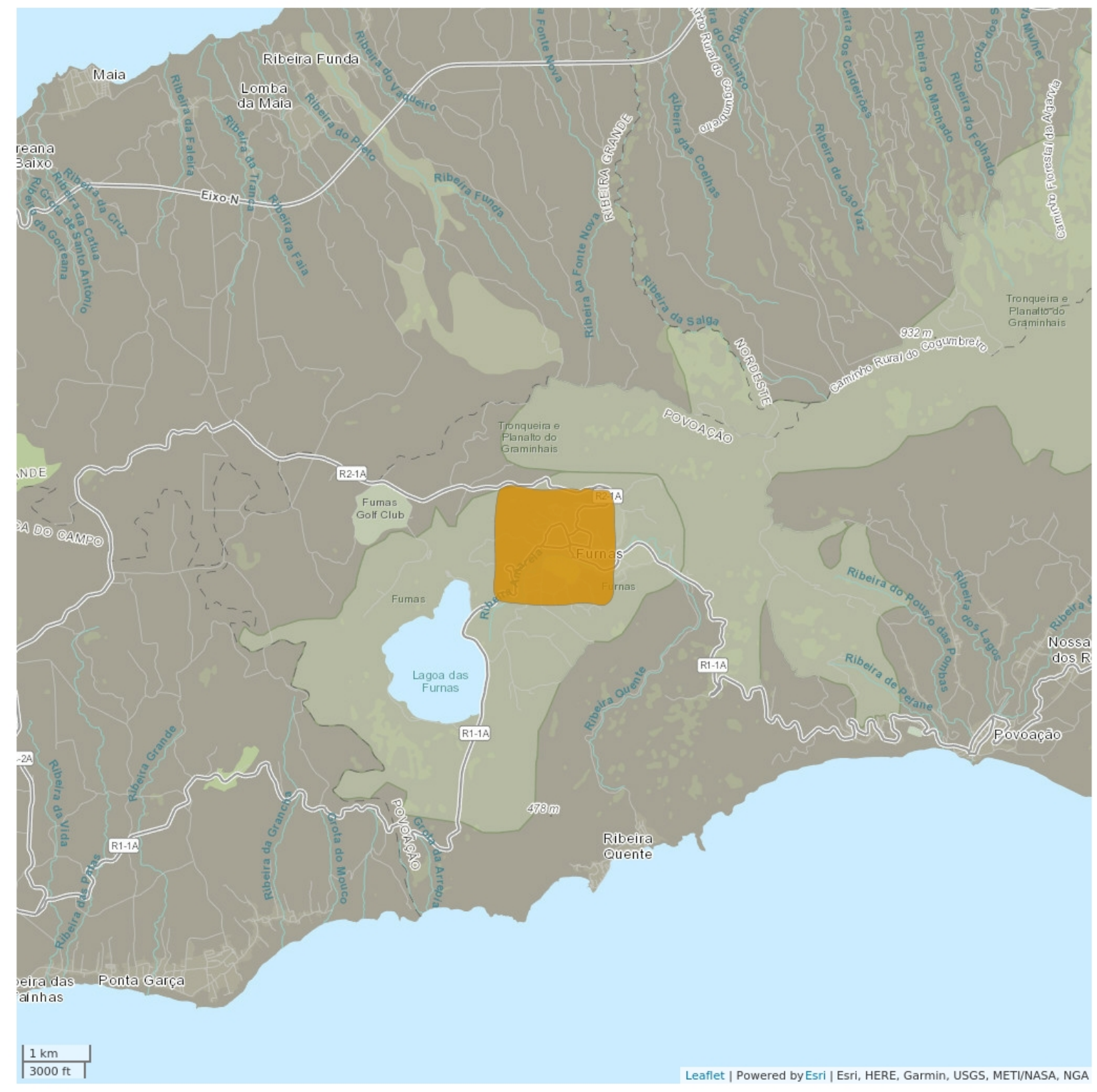

Legend

EXTANT (RESIDENT)
Compiled by:

Azorean Biodiversity Group 2018

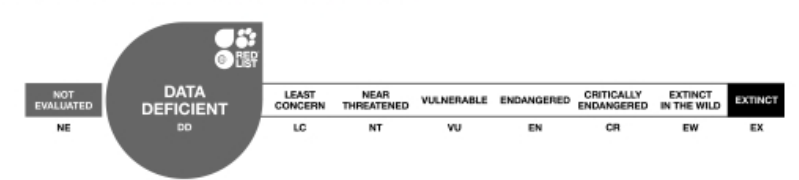

\section{8: G Rist}

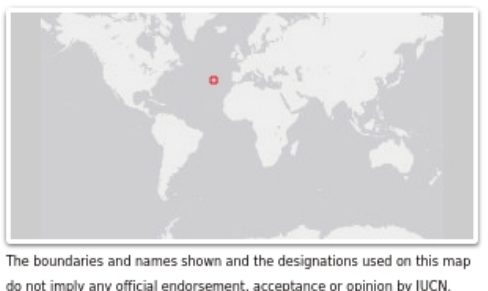




\section{Population}

No current population size estimates exist for this species.

Current Population Trend: Unknown

\section{Habitat and Ecology (see Appendix for additional information)}

The ecology and traits of this species are unknown. Mycetophilidae occur mainly in humid areas like moist forests (McAlpine et al. 1981), but are also quite common in swamps, or live in the moister parts of heath and open grassland, and some species have been recorded on mosses and liverworts. The larvae of many species live in fleshy or woody fungi or in dead wood and usually feed on fungi, especially the fruiting bodies, but also spores and hyphae. Nevertheless, the larvae of some species, while still being associated with fungi, are at least partly predatory (McAlpine et al. 1981). A few species are monophagous or polyphagous, but the majority of species are restricted to particular genera or families of fungi. Pupation usually takes place in the ground but some species pupate in the host fungus (McAlpine et al. 1981). Where the larvae are known, species of the genus Rymosiaa develop in soft terrestrial fungi, like agarics (Chandler and Ribeiro 1995).

Systems: Terrestrial

\section{Threats (see Appendix for additional information)}

A lack of information regarding the present status of this species precludes an assessment of potential threats. Nevertheless, the ecology of other members of the Mycetophilidae family suggests that this species might be affected by future habitat declines as a consequence of climate change (Ferreira et al., 2016) and increased droughts. Given that this species was collected in the vicinity of hot springs, future violent geothermal events might as well affect it. Additionally, Rymosia azorensis was collected from a highly disturbed site, so past and present human disturbance and land use changes, coupled with habitat degradation by invasive species might have also affected this species.

\section{Conservation Actions (see Appendix for additional information)}

The species is not protected by regional law. The present situation of this species needs to be further assessed, and further research is needed into its population, distribution, threats, ecology and life history. From what is known, conservation of natural habitats and other wet areas, together with problematic species control, could potentially aid this species' conservation. This species is known to have been present in one area that is now highly disturbed, but included in the Natural Park of S. Miguel.

\section{Credits}

Assessor(s): $\quad$ Nunes, R. \& Borges, P.A.V.

Reviewer(s): $\quad$ Russell, N. 


\section{Bibliography}

Borges, P.A.V., Costa, A., Cunha, R., Gabriel, R., Gonçalves, V., Martins, A.F., Melo, I., Parente, M., Raposeiro, P., Rodrigues, P., Santos, R.S., Silva, L., Vieira, P. and Vieira, V. 2010. A list of the terrestrial and marine biota from the Azores. Princípia, Cascais.

Chandler, P. and Ribeiro, E. 1995. The Sciaroidea (Diptera) (excluding Sciaridae) of the Atlantic islands (Canary Islands, Madeira and the Azores). Boletim do Museu Municipal do Funchal 3: 1-170.

Ferreira, M.T., Cardoso, P., Borges, P.A.V., Gabriel, R., Azevedo, E.B., Reis, F., Araújo, M.B. and Elias, R.B. 2016. Effects of climate change on the distribution of indigenous species in oceanic islands (Azores). Climate Change 138(3-4): 603-615.

Frey, R. 1945. Tiergeographische studen über die Dipterenfauna der Azores. Commentatione biologicae 8(10): 1-114.

IUCN. 2020. The IUCN Red List of Threatened Species. Version 2020-3. Available at: $\underline{w w w . i u c n r e d l i s t . o r g . ~}$ (Accessed: 10 December 2020).

McAlpine, J.F., Peterson, B.V., Shewell, G.E., Teskey, H.J., Vockeroth, J.R. and Wood, D.M. 1981. Manual of Nearctic Diptera - Volume 1. Research Branch, Agriculture Canada, Ottawa.

\section{Citation}

Nunes, R. \& Borges, P.A.V. 2020. Rymosia azorensis. The IUCN Red List of Threatened Species 2020:

e.T124915769A124930761. https://dx.doi.org/10.2305/IUCN.UK.2020-

3.RLTS.T124915769A124930761.en

\section{Disclaimer}

To make use of this information, please check the Terms of Use.

\section{External Resources}

For Supplementary Material, and for Images and External Links to Additional Information, please see the Red List website. 


\section{Appendix}

\section{Habitats}

(http://www.iucnredlist.org/technical-documents/classification-schemes)

\begin{tabular}{|c|c|c|c|}
\hline Habitat & Season & Suitability & $\begin{array}{l}\text { Major } \\
\text { Importance? }\end{array}$ \\
\hline 1. Forest $->$ 1.4. Forest - Temperate & Resident & Suitable & Yes \\
\hline 5. Wetlands (inland) -> 5.12. Wetlands (inland) - Geothermal Wetlands & Resident & Suitable & - \\
\hline
\end{tabular}

\section{Threats}

(http://www.iucnredlist.org/technical-documents/classification-schemes)

\begin{tabular}{|c|c|c|c|c|}
\hline Threat & Timing & Scope & Severity & Impact Score \\
\hline \multirow{3}{*}{$\begin{array}{l}\text { 8. Invasive and other problematic species, genes \& } \\
\text { diseases -> 8.1. Invasive non-native/alien } \\
\text { species/diseases -> 8.1.1. Unspecified species }\end{array}$} & Ongoing & Unknown & $\begin{array}{l}\text { Slow, significant } \\
\text { declines }\end{array}$ & Unknown \\
\hline & Stresses: & \multirow{2}{*}{\multicolumn{3}{|c|}{$\begin{array}{l}\text { 1. Ecosystem stresses } \rightarrow 1.2 \text {. Ecosystem degradation } \\
\text { 1. Ecosystem stresses } \rightarrow 1.3 \text {. Indirect ecosystem effects }\end{array}$}} \\
\hline & & & & \\
\hline \multirow[t]{2}{*}{ 10. Geological events -> 10.1. Volcanoes } & Future & Unknown & $\begin{array}{l}\text { Very rapid } \\
\text { declines }\end{array}$ & Unknown \\
\hline & Stresses: & \multicolumn{3}{|c|}{$\begin{array}{l}\text { 1. Ecosystem stresses }->1.2 \text {. Ecosystem degradation } \\
\text { 2. Species Stresses }->2.1 \text {. Species mortality }\end{array}$} \\
\hline \multirow[t]{2}{*}{$\begin{array}{l}\text { 11. Climate change \& severe weather }->11.1 \text {. Habitat } \\
\text { shifting \& alteration }\end{array}$} & Future & Unknown & $\begin{array}{l}\text { Slow, significant } \\
\text { declines }\end{array}$ & Unknown \\
\hline & Stresses: & \multicolumn{3}{|c|}{$\begin{array}{l}\text { 1. Ecosystem stresses }->1.1 \text {. Ecosystem conversion } \\
\text { 1. Ecosystem stresses }->1.2 \text {. Ecosystem degradation } \\
\text { 1. Ecosystem stresses }->1.3 \text {. Indirect ecosystem effects }\end{array}$} \\
\hline \multirow[t]{2}{*}{$\begin{array}{l}\text { 11. Climate change \& severe weather -> 11.2. } \\
\text { Droughts }\end{array}$} & Future & Unknown & $\begin{array}{l}\text { Slow, significant } \\
\text { declines }\end{array}$ & Unknown \\
\hline & Stresses: & \multicolumn{3}{|c|}{$\begin{array}{l}\text { 1. Ecosystem stresses }->1.2 \text {. Ecosystem degradation } \\
\text { 1. Ecosystem stresses }->1.3 \text {. Indirect ecosystem effects }\end{array}$} \\
\hline
\end{tabular}

\section{Conservation Actions in Place}

(http://www.iucnredlist.org/technical-documents/classification-schemes)

\begin{tabular}{|l|}
\hline Conservation Action in Place \\
\hline In-place research and monitoring \\
\hline Action Recovery Plan: No \\
\hline Systematic monitoring scheme: No \\
\hline In-place land/water protection \\
\hline Occurs in at least one protected area: Yes \\
\hline
\end{tabular}




\section{Conservation Actions Needed}

(http://www.iucnredlist.org/technical-documents/classification-schemes)

\section{Conservation Action Needed}

2. Land/water management -> 2.1. Site/area management

2. Land/water management -> 2.2. Invasive/problematic species control

\section{Research Needed}

(http://www.iucnredlist.org/technical-documents/classification-schemes)

\begin{tabular}{|l|}
\hline Research Needed \\
\hline 1. Research $->$ 1.2. Population size, distribution \& trends \\
\hline 1. Research $->$ 1.3. Life history \& ecology \\
\hline 1. Research $->$ 1.5. Threats \\
\hline 3. Monitoring $->$ 3.1. Population trends \\
\hline 3. Monitoring $->$ 3.4. Habitat trends \\
\hline
\end{tabular}

\section{Additional Data Fields}

\begin{tabular}{|l|}
\hline Distribution \\
\hline Estimated area of occupancy (AOO) $\left(\mathrm{km}^{2}\right): 8$ \\
\hline Continuing decline in area of occupancy (AOO): Unknown \\
\hline Estreme fluctuations in area of occupancy (AOO): Unknown \\
\hline Continuing decline in extent of occurrence (EOO): Unknown \\
\hline Extreme fluctuations in extent of occurrence (EOO): Unknown \\
\hline Continuing decline in number of locations: Unknown \\
\hline Extreme fluctuations in the number of locations: Unknown \\
\hline Lower elevation limit (m): 200 \\
\hline Upper elevation limit (m): 400 \\
\hline Population \\
\hline Continuing decline of mature individuals: Unknown \\
\hline Extreme fluctuations: Unknown \\
\hline Population severely fragmented: Unknown \\
\hline
\end{tabular}




\section{The IUCN Red List Partnership}

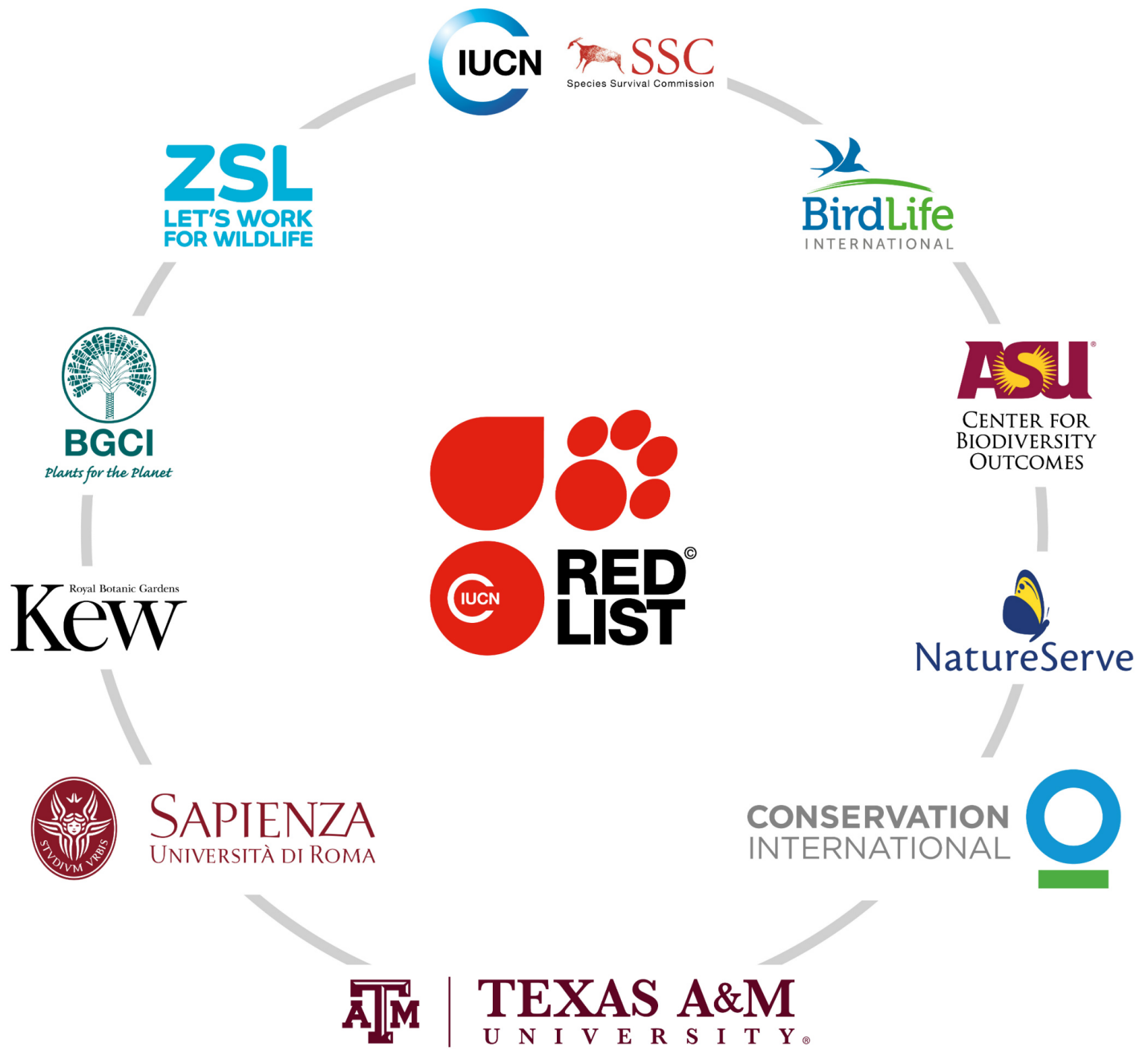

The IUCN Red List of Threatened Species ${ }^{\mathrm{TM}}$ is produced and managed by the IUCN Global Species Programme, the IUCN Species Survival Commission (SSC) and The IUCN Red List Partnership.

The IUCN Red List Partners are: Arizona State University; BirdLife International; Botanic Gardens Conservation International; Conservation International; NatureServe; Royal Botanic Gardens, Kew; Sapienza University of Rome; Texas A\&M University; and Zoological Society of London. 